ISSN 1392-3196 / e-ISSN 2335-8947

Zemdirbyste-Agriculture, vol. 107, No. 4 (2020), p. 323-328

DOI 10.13080/z-a.2020.107.041

\title{
Trends changes of oat genotypes grown in Lithuania
}

\author{
Vida DANYTĖ, Andrii GORASH, Aurelija LIATUKIENĖ, Žilvinas LIATUKAS \\ Lithuanian Research Centre for Agriculture and Forestry, Institute of Agriculture \\ Instituto 1, Akademija, Kèdainiai distr., Lithuania \\ E-mail: vida.danyte@lammc.lt
}

\begin{abstract}
A study was carried out at Institute of Agriculture, Lithuanian Research Centre for Agriculture and Forestry. A total of 37 oat (Avena sativa L.) genotypes, which had been registered, grown or selected in Lithuania over the period 1934-2013 were analysed. Precision field trials were conducted. Conventional technology for oat cultivation was employed. The relationship between oat genotypes and year of registration, growth and selection was calculated. The greatest progress of oat genotypes registered, grown or selected in Lithuania was in the increase of yield $(R=0.73)$, hectolitre weight $(R=0.53)$, and plant height decrease $(R=-0.57)$; the highest decrease was found in protein content $(R=-0.55)$. The new cultivars tended to show a higher thousand grain weight, better resistance to lodging, higher starch and lower fat content, lower resistance to crown rust.
\end{abstract}

Key words: Avena sativa, genotypes, yield.

\section{Introduction}

During the last two decades (1999-2018), the total global area sown to oats has decreased from 12.7 to 9.8 million ha and from 8.6 to 5.9 million ha in Europe. The global average yield of oats increased from 1.9 to $2.3 \mathrm{t} \mathrm{ha}^{-1}$ and from 1.8 to $2.3 \mathrm{tha}^{-1}$ in Europe. In contrast to the global trends, in Lithuania, the oat production area has increased twice from 51.2 to 102.9 thousand ha, and the yield increased from 1.8 to $2.6 \mathrm{t} \mathrm{ha}^{-1}$ (Fig. 1) (data $2.6 \mathrm{t} \mathrm{ha}^{-1}$ was taken from the year 2017 , because 2018 was extremely rainy). A lot of cereal crops were not harvested, and the official statistical data do not reflect the actual situation (FAOSTAT, http://www.fao.org/faostat/ en/\#data/QC) (Fig. 2).

Decreasing oat area lead to a vicious circle with decreasing of breeding programs, poor genetic diversity, low yielding cultivars, poor breeding achievements and, finally, again decreasing area. During the last two decades in Austria and Germany the number of oat breeding programs has decreased by more than $80 \%$ (Achleitner et al., 2008; Leišová-Svobodová et al., 2019). Conservation of oat genetic resources is important for the world's food security (Boczkowska, Tarczyk, 2013).

Plant breeders have been working for a long time to develop high-yield and consistent good quality cultivars. Such cultivars are also desired to be adapted to a wide range of environments. The yield and quality traits are greatly influenced by genotypes and environmental factors (Mut et al., $2018 \mathrm{~b}$ ).
Oat breeding was started in Lithuania in 1922. During the first 10 years' period, the main breeding method was individual selection. Later the initial material in most cases was developed by the method of intervarietal hybridization. Oat cultivars 'Stipruolès', 'Dotnuvos baltosios', 'Gyrūnès', 'Skaistūnès', 'Sidabrès', 'Šušvè', 'Jaugila', 'Migla DS' and hulless 'Mina DS' have been developed during a 90 years' period (Kulikauskas, Sprainaitienè, 1998; Danyte, 2012).

The primary breeding goal is improvement in grain yield, and plant breeders have been working for a long time to achieve high yield and good grain quality criteria in cultivars (Mut et al., 2016; 2018 a; b). The genotype and climate conditions are the main parameters that greatly influence yield and quality of oats (Buerstmayr et al., 2007; Mut et al., 2018 a). To face the challenge of decreasing area, declining number of breeding programs and changing environmental conditions, caused by the global warming, a more efficient description and exploitation of oat genetic resources is necessary to secure oat production and thereby retain agricultural diversity. Progress in yield and yield stability is of utmost importance, irrespective of the scientifically well described nutritional benefits (Leišová-Svobodová et al., 2019).

The aim of the current study was to analyse the development of oat (Avena sativa L.) genotypes, grown in Lithuania over the period 1934-2013.

Please use the following format when citing the article:

Danytė V., Gorash A., Liatukiené A., Liatukas Ž. 2020. Trends changes of oat genotypes grown in Lithuania. Zemdirbyste-Agriculture, 107 (4): 323-328. DOI 10.13080/z-a.2020.107.041 


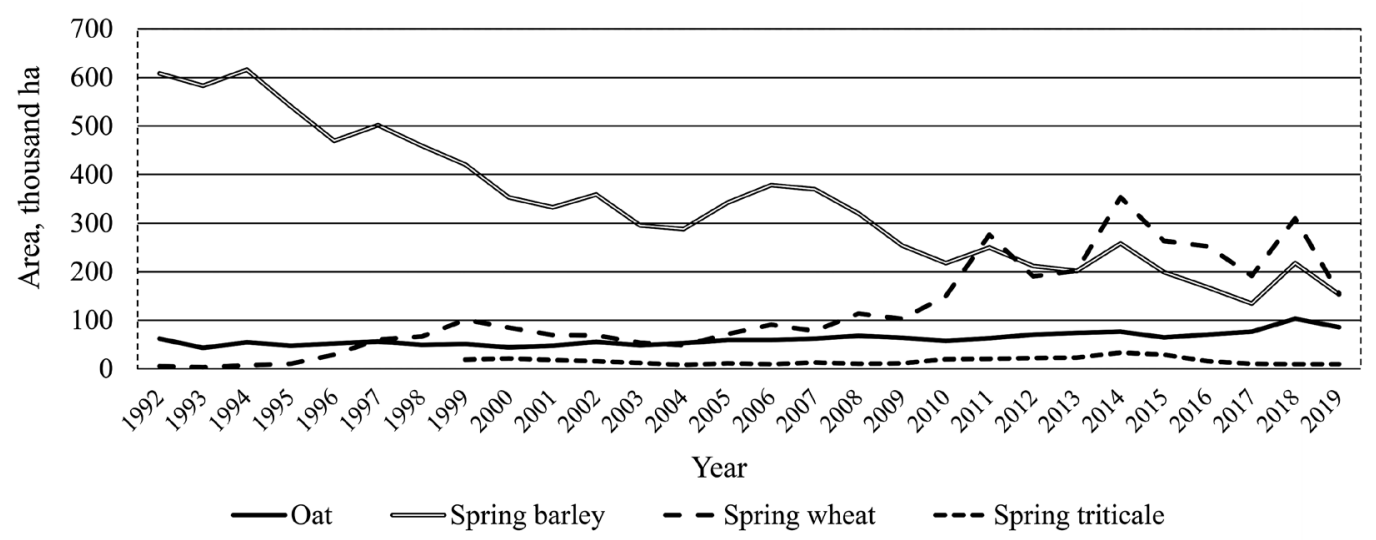

Figure 1. Area of spring cereals in Lithuania

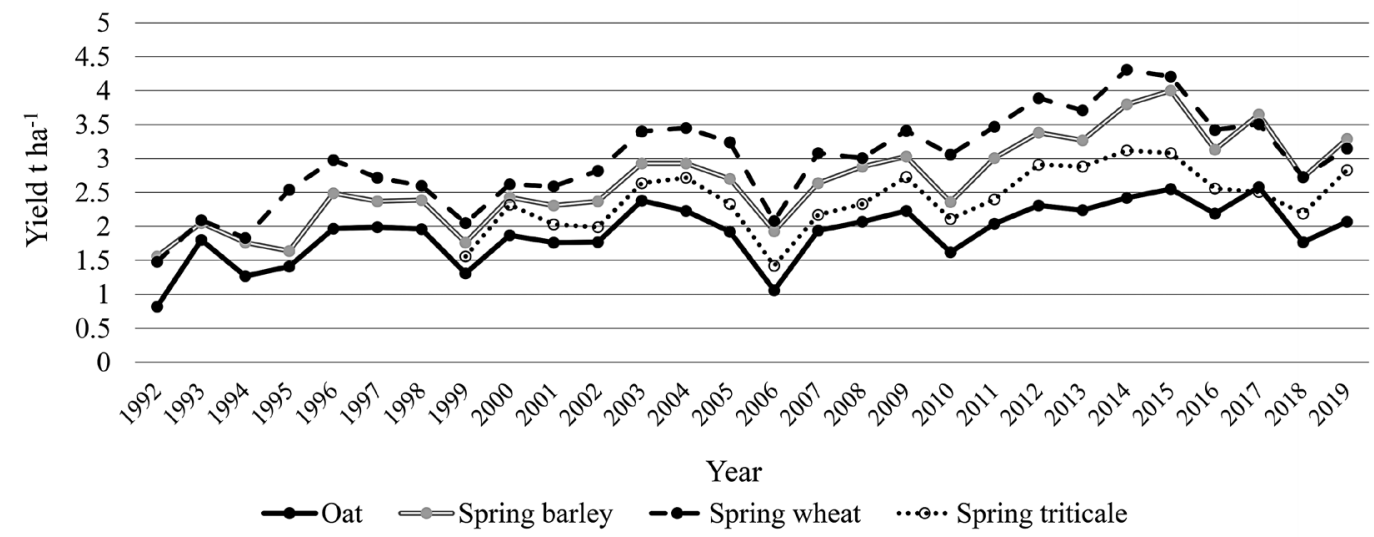

Figure 2. Yield of spring cereals in Lithuania

\section{Materials and methods}

Field trials. Precision field trials were conducted in 2013-2014 in the central part of Lithuania (Akademija, Kedainiai distr.), at Research Centre for Agriculture and Forestry, Institute of Agricultures, Department of Cereal Breeding. The field trials were laid out in a randomized block design. The crop was planted at a rate of 5 million seeds ha ${ }^{-1}$ with a small plot sowing machine Hege (Wintersteiger, Austria) both year within the last week of April. A plot size of $5.0 \times 1.5 \mathrm{~m}^{2}$ was used in four replications. Conventional technology for oat cultivation was employed. The soil type of the experimental site $\left(55^{\circ} 39^{\prime} \mathrm{N}, 2^{\circ} 86^{\prime} \mathrm{E}\right)$ was light loamy EndocalcariEpihypogleyic Cambisol (WRB, 2014) with P 184-219 $\mathrm{mg} \mathrm{kg}{ }^{-1}$ and $\mathrm{K} 152-201 \mathrm{mg} \mathrm{kg}^{-1}$.

Lodging was estimated in points $1-9$, where $9-$ no lodging. Loose smut (Ustilago avenae) was estimated in damaged panicles per plot. Crown rust (Puccinia coronata) and Helminthosporium leaf spot (Dreshlera avenae) were estimated in points $0-9$, where $0-$ no disease.

Grain was harvested at full ripening with a plot combine Wintersteiger Classic (Austria). Grain yield was evaluated by weighing grain of each plot and recalculating to tons per hectare at a standard $14 \%$ grain moisture content.

Genotypes. Thirty-seven oat genotypes, which were registered, grown or selected in Lithuania over the period 1934-2013, were analysed (Table 1). 'Viva DS', registered in 2015, was included in the experiment as a promising cultivar. Two naked oat cultivars (Czech 'Abel' and Lithuanian 'Mina DS') were registered during this period, but they were not included in the experiment, because naked oats are not comparable with husked oats. Meteorological conditions. Different genotypes of cereals respond differently to agroclimatic conditions of a particular area due to the difference in their genetic makeup and physical life process. Selection of improved and high yielding genotypes having a wide range of adaptation to agroclimatic conditions is essential to increase grain yield (Shah et al., 2002).

The spring of 2013 was late and short. In May, the weather was hot and summer-like. In spring months precipitation was $104.4 \mathrm{~mm}$, or $89 \%$ of many years' average. The summer was warm, with a varying amount of precipitation. The temperature of each summer month was higher than many years' average. Average summer day temperature was $18.4^{\circ} \mathrm{C}$, and many years' average was $16.7^{\circ} \mathrm{C}$. The spring of 2014 was early. Spring and summer were variable in temperature and amount of precipitation. Average spring months' temperature was $3.1^{\circ} \mathrm{C}$ higher than many years' average. Precipitation was $135.3 \mathrm{~mm}$, or $116 \%$ of many years' average.

Statistical analysis. The relationship between genotypes' traits and year of genotype registration, growth or selection was evaluated using the correlationregression analysis with the statistical software $S A S$ Enterprise Guide, version 7.13 (SAS Institute Inc., USA). 
Table 1. Genotypes registered, grown or selected in Lithuania

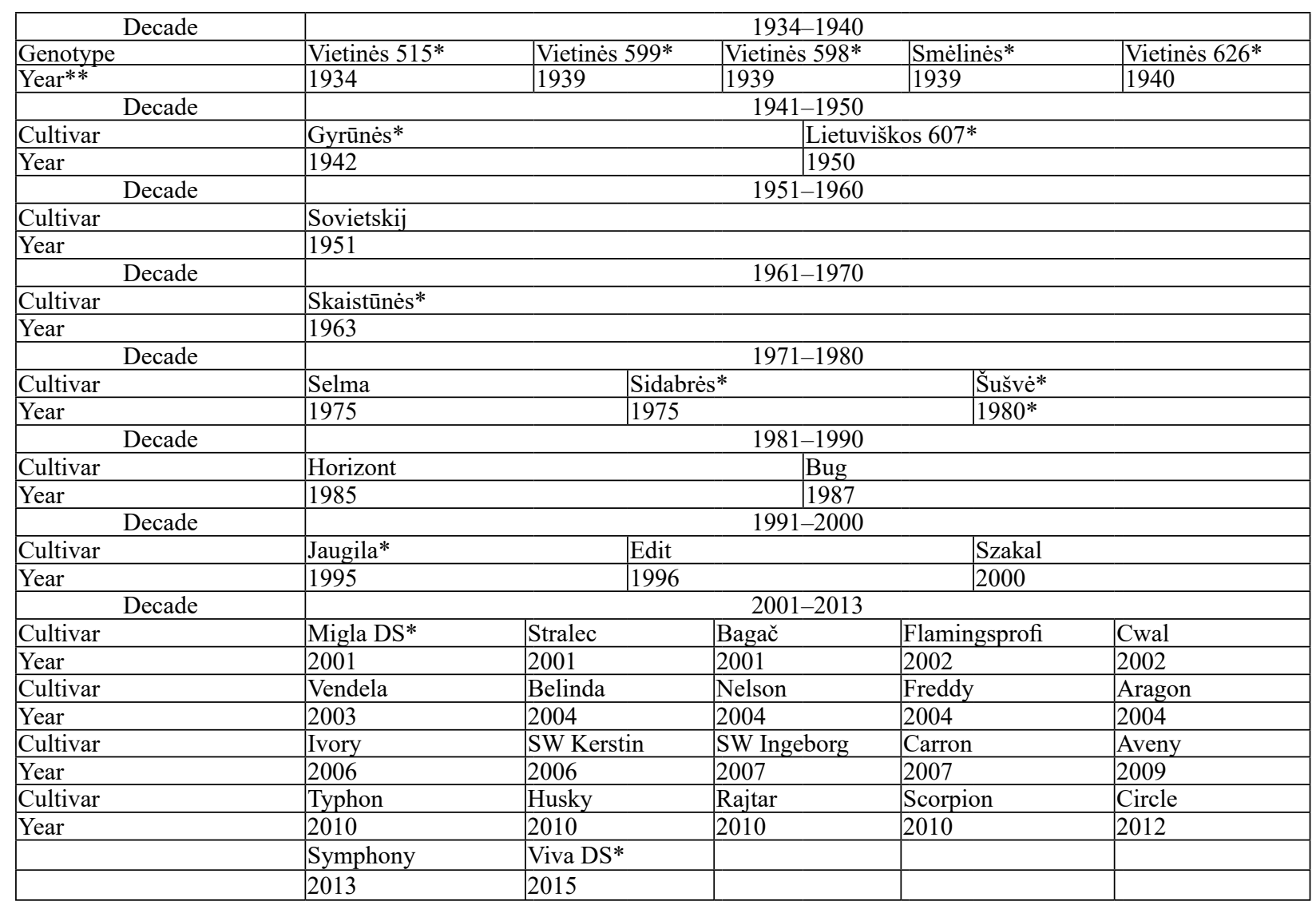

* - genotypes of Lithuanian origin; ** - year of cultivar registration, release or landrace selection time

\section{Results and discussion}

Grain yield. The main goals of plant breeders are not only to release high-yielding and high-quality cultivars for final users, but also to identify promising parents for the future breeding programs (Shah et al., 2002; Mut et al., 2016; 2018 b; Michel et al., 2019). Environmental factors have great influence on oat grain yield and quality (Zhou et al., 1999), but Herrera et al. (2016) proposed to select specific oat cultivars for having higher effect on grain quality.

As it had been expected, the strongest relationship was found between oat grain yield and year of registration or cultivation (Table 2). The oldest known Lithuanian landraces ('Vietinès 515', 'Vietinès 599', 'Vietinès 598', 'Vietinès 626', 'Lietuviškos 607') and cultivars 'Skaistūnès', 'Šušvè' and 'Sidabrès' were among the lowest yielding genotypes (Table 3).

The lowest average yield of all investigated genotypes was determined for the cultivar 'Skaistūnès', grown from 1963, and the highest yield was recorded for Swedish cultivar 'Aveny', registered in 2009. The progress in yield was $2.4 \mathrm{t} \mathrm{ha}^{-1}$ per 46 years. The difference between the average yield of Lithuanian cultivar 'Jaugila', which was registered in 1995 and was popular for a long time after registration, and that of Lithuanian cultivar 'Migla DS', which was registered

Table 2. The relationship between oat traits and year of cultivar registration, release or selection time (year)

\begin{tabular}{|c|c|c|c|}
\hline Equation & Relationship & $\begin{array}{l}\text { Correlation } \\
\text { coefficient }\end{array}$ & $P$ value \\
\hline Yield t ha ${ }^{-1}=-39.4423+0.0219378 \times$ year & moderately strong & $R=0.73$ & 0.0000 \\
\hline Plant height $\mathrm{cm}=744.775-0.316514 \times$ year & moderately strong & $R=-0.57$ & 0.0000 \\
\hline Lodging, points $=-11.0841+0.00972585 \times$ year & relatively weak & $R=0.22$ & 0.0000 \\
\hline Heading time, days after sowing $=11.0841+0.00972585 \times$ year & relatively weak & $R=0.12$ & 0.0250 \\
\hline Hectolitre weight $\mathrm{g} \mathrm{L}^{-1}=-7.13476+0.0302748 \times$ year & moderately strong & $R=0.53$ & 0.0005 \\
\hline Thousand grain weight $\mathrm{g}=-112.218+0.0748006 \times$ year & relatively weak & $R=0.38$ & 0.0129 \\
\hline Husk content $\%=54.0782-0.0144722 \times$ year & relatively weak & $R=-0.11$ & 0.4991 \\
\hline Protein $\%=41.8123+0.0148162 \times$ year & moderately strong & $R=-0.55$ & 0.0002 \\
\hline Starch, $\%=-25.5393+0.0335789-$ year & relatively weak & $R=0.39$ & 0.0121 \\
\hline Fat $\%=-23.4165+0.0096668 \times$ year & relatively weak & $R=-0.41$ & 0.0088 \\
\hline Resistance to loose smut, points $=-85.9147+0.0536246 \times$ year & relatively weak & $R=0.03$ & 0.4770 \\
\hline Resistance to $?$ crown rust, points $=-18.8757+0.0102306 \times$ year & relatively weak & $\mathrm{R}=0.23$ & 0.0000 \\
\hline Resistance to Helminthosporium leaf spot, points $=3.37767-0.000749212 \times$ year & relatively weak & $R=-0.03$ & 0.5023 \\
\hline
\end{tabular}


Table 3. Agronomic traits, which are correlated with year of cultivar registration, growth or selection time, 2013-2014

\begin{tabular}{|c|c|c|c|c|}
\hline Genotype & $\begin{array}{l}\text { Yield } \\
\mathrm{t} \mathrm{ha}^{-1}\end{array}$ & $\begin{array}{l}\text { Plant } \\
\text { height } \\
\mathrm{cm}\end{array}$ & $\begin{array}{l}\text { Heading } \\
\text { time, } \\
\text { days after } \\
\text { sowing }\end{array}$ & $\begin{array}{c}\text { Protein } \\
\text { content } \\
\%\end{array}$ \\
\hline Decade & \multicolumn{4}{|c|}{$1934-1940$} \\
\hline Vietinès 515 & 3.15 & 131 & 60.9 & 12.7 \\
\hline Vietinès 599 & 3.15 & 129 & 61.9 & 13.2 \\
\hline Vietinès 598 & 3.42 & 127 & 60.0 & 12.6 \\
\hline Smèlinès & 4.56 & 129 & 58.6 & 12.3 \\
\hline Vietinès 626 & 3.47 & 129 & 60.5 & 13.4 \\
\hline Decade & \multicolumn{4}{|c|}{ 1941-1950 } \\
\hline Gyrūnès & 3.72 & 119 & 58.1 & 12.5 \\
\hline Lietuviškos 607 & 3.30 & 132 & 58.5 & 13.8 \\
\hline Decade & \multicolumn{4}{|c|}{$1951-1960$} \\
\hline Sovietskij & 3.70 & 133 & 61.7 & 12.9 \\
\hline Decade & \multicolumn{4}{|c|}{$1961-1970$} \\
\hline Skaistūnès & 3.05 & 128 & 59.4 & 13.7 \\
\hline Decade & \multicolumn{4}{|c|}{ 1971-1980 } \\
\hline Selma & 3.85 & 122 & 59.3 & 12.0 \\
\hline Sidabrès & 3.69 & 119 & 58.4 & 13.4 \\
\hline Šušvė & 3.48 & 127 & 60.0 & 13.3 \\
\hline Decade & \multicolumn{4}{|c|}{$1981-1990$} \\
\hline Horizont & 4.35 & 126 & 58.9 & 12.2 \\
\hline Bug & 4.61 & 127 & 58.4 & 11.9 \\
\hline Decade & \multicolumn{4}{|c|}{ 1991-2000 } \\
\hline Jaugila & 4.09 & 121 & 58.8 & 12.9 \\
\hline Edit & 5.02 & 106 & 59.3 & 12.1 \\
\hline Szakal & 4.28 & 112 & 59.3 & 12.0 \\
\hline Decade & \multicolumn{4}{|c|}{$2001-2015$} \\
\hline Migla DS & 4.71 & 129 & 59.2 & 12.6 \\
\hline Stralec & 4.89 & 100 & 58.6 & 13.3 \\
\hline Bagač & 4.60 & 111 & 58.8 & 13.3 \\
\hline Flamingsprofi & 4.76 & 111 & 57.8 & 11.1 \\
\hline Cwal & 5.15 & 114 & 59.1 & 11.7 \\
\hline Vendela & 5.09 & 106 & 58.7 & 12.2 \\
\hline Belinda & 4.84 & 106 & 58.1 & 12.6 \\
\hline Nelson & 4.80 & 109 & 58.4 & 11.4 \\
\hline Freddy & 4.70 & 111 & 58.8 & 11.9 \\
\hline Aragon & 4.47 & 114 & 59.2 & 12.8 \\
\hline Ivory & 4.86 & 104 & 57.2 & 12.1 \\
\hline SW Kerstin & 4.92 & 107 & 60.0 & 11.6 \\
\hline SW Ingeborg & 5.08 & 100 & 59.3 & 11.9 \\
\hline Carron & 4.88 & 96 & 57.7 & 11.1 \\
\hline Aveny & 5.49 & 112 & 58.4 & 12.0 \\
\hline Typhon & 4.61 & 109 & 57.4 & 12.3 \\
\hline Husky & 5.09 & 116 & 70.0 & 11.8 \\
\hline Rajtar & 5.39 & 107 & 58.0 & 11.2 \\
\hline Scorpion & 4.78 & 112 & 57.3 & 11.7 \\
\hline Viva DS & 5.05 & 102 & 56.5 & 12.5 \\
\hline Symphony & 4.69 & 106 & 57.0 & 11.5 \\
\hline Circle & 4.85 & 111 & 59.4 & 12.0 \\
\hline Average & 4.44 & 115 & 58.9 & 12.3 \\
\hline $\mathrm{LSD}_{05}$ & 0.530 & 9.7 & 5.60 & 1.2 \\
\hline
\end{tabular}

in 2001 (6 years later), was $0.62 \mathrm{t} \mathrm{ha}^{-1}$. The difference between the year of release of 'Skaistūnès' and 'Migla DS' is 38 years, and the difference between their yield is $1.66 \mathrm{t} \mathrm{ha}^{-1}$. The average yield of Lithuanian cultivar 'Viva DS', which is becoming popular now, was $5.05 \mathrm{t} \mathrm{ha}^{-1}$; the progress was $0.34 \mathrm{t} \mathrm{ha}^{-1}$ per 14 years.

The difference between average grain yield of Lithuanian and foreign oat cultivars was $1.01 \mathrm{t} \mathrm{ha}^{-1}$ (3.76 and $4.77 \mathrm{t} \mathrm{ha}^{-1}$ ). But it cannot be concluded that foreign cultivars are better than Lithuanian, because foreign genotypes came to Lithuania markedly latter. Seven Lithuanian genotypes from the period 1934-1950 were analysed. The first foreign cultivar 'Sovietskij' was registered in 1951. It was a Ukrainian cultivar. The first cultivar from Scandinavia was registered in 1975. It was a Swedish cultivar 'Selma'.

Compared to other cereals, oat grains are unique by their quality (Butt et al., 2008). Quality criteria are as important as high yield potential. Criteria generally used to describe oat quality include test weight, thousand grain weight, husk content and grain chemical composition, mainly protein and fat concentration (Douhlert et al., 2001; Mut et al., 2016).

Protein content is the main indicator of oat grain quality. Protein content in oat grain of the same cultivar can vary by $3-4 \%$, when it is grown in different geographical regions (Mut et al., 2018 b). Peterson et al. (2005) reported that the grain protein content varied from $10.0 \%$ to $18.0 \%$ in hulled oat genotypes. The protein content of the hulless oat groat ranges from $12 \%$ to $24 \%$, and it is the highest among cereals (Butt et al., 2008; Ahmad et al., 2014). In the experiment of Guo et al. (2014) in China, the content of protein in hulled oat ranged from $14.7 \%$ to $20.0 \%$, and its average was $17.4 \%$. In our experiment, the average protein content was much lower $-12.3 \%$. The lowest protein content in the grain of the investigated oat genotypes was of cultivars 'Flamingsprofi' and 'Carron', the highest - of landrace 'Lietuviškos 607'. Cultivars registered after 2000 and 'Bug' registered in 1987 had the lowest grain protein content (11.1-11.9\%). Mostly old genotypes, registered in 1939-1980, and two newer cultivars 'Stralec' and 'Bagač', which were registered in 2001, had the highest protein content (13.2-13.8\%). Some new and old genotypes had the same grain protein content - 'Smèlinès' (grown in 1939) and 'Typhon' (registered in 2010) had $12.3 \%$ of protein in grain, and 'Gyrūnès' (grown in 1942) and 'Viva DS' (registered in 2015) had $12.5 \%$ of protein in grain. The correlation coefficient shows a decline of protein content in the grain of new oat genotypes.

Starch content. Starch is the most abundant component of oat grain, and it usually fluctuates between $30 \%$ and $60 \%$ (Guo et al., 2014; Punia et al., 2020). Starch content in the grain of the investigated oat genotypes ranged from $36.3 \%$ to $44.7 \%$. The highest percent of starch was determined in the cultivars registered in 2000 and later, and in two older Sweden cultivars 'Selma' (registered in 1975) and 'Edit' (registered in 1996). Cultivars 'Stralec' and 'Bagač', which had high protein content, had the lowest starch content. A moderately strong negative relationship was found between protein and starch content $(-0.57, p=0.0001)$ and between fat and starch content $(-0.64, p=0.0000)$ in the grain of the investigated oat genotypes. The relationship between fat and protein content was relatively week $(0.46$, $p=0.0028$ ).

Fat content. There was no clear decrease in fat content, as it was noticed in protein content in grain and year of cultivar registration, release or landraces selection time (year). Fat content fluctuated from 3.09\% ('Typhon') to 5.51 ('Aragon'). Other researchers reported a fat content in oat grain ranging from $2 \%$ to $12 \%$ (Aro et al., 2007) or from $4.0 \%$ to $7.9 \%$ with an average of $5.95 \%$ (Guo et al., 2014).

Hectolitre weight, thousand-grain weight and husk content also are important indicators of oat 
grain quality (Yan et al., 2016; Mut et al., 2018 b). A moderately strong relationship between hectolitre weight and year illustrates progress in this trait. The highest $559 \mathrm{~g} \mathrm{~L}^{-1}$ hectolitre weight was of the newest Lithuanian cultivar 'Viva DS'. Very good hectolitre weight was also shown by the older Lithuanian cultivar 'Migla DS' $548 \mathrm{~g} \mathrm{~L}^{-1}$. Some Lithuanian landraces also had rather good hectolitre weight, e.g., 'Vietinès 598' had $536 \mathrm{~g} \mathrm{~L}^{-1}$. But landrace 'Vietinès 599', which was grown at the same time as 'Vietinès 598', had the lowest $482 \mathrm{~g} \mathrm{~L}^{-1}$ hectolitre weight. The relationship between hectolitre weight and year of foreign cultivars was relatively week $(R=0.34)$.

Lodging. Reduced lodging is of vital importance for oat cultivar improvement (Wu, Ma, 2019). Modern cultivars tend to be more resistant to lodging. Lithuanian landraces had 8.1 or less points. The newest Lithuanian cultivar 'Viva DS' had 8.8 points, and only two cultivars 'Carron' and 'Ingeborg' were more resistant to lodging. But cultivar 'Migla DS' registered in 2001 showed similar resistance to lodging as landraces -7.7 points.

Plant height. Short cereal plant height is a very important requirement for modern cultivars (Nersting et al., 2006). A moderately strong negative relationship between plant height and year proved this statement. A moderately strong negative relationship $(R=-0.59$, $p=0.0049$ ) also was found between plant height and plant grain yield. Oat plants of Lithuanian genotypes was significantly higher $(125.3 \mathrm{~cm})$ compared with foreign genotypes $(110.6 \mathrm{~cm})$. But the situation was similar to that of grain yield - there were more old genotypes between Lithuanian genotypes, and they were lower yielding and taller. For example, the tallest cultivar was 'Sovietskij' $(133.0 \mathrm{~cm})$, which is a foreign cultivar registered in 1951, and modern Lithuanian cultivar 'Viva DS' $(102.5 \mathrm{~cm})$ was the fourth shortest cultivar registered in 2015.

Thousand grain weight (TGW). Buerstmayr et al. (2007) suggest that TGW depends most on the genotype and depends less on the treatments or environment. Tamm (2003) emphasizes that yield and grain quality are influenced most by climate and genotype. TGW has reached an optimum level after the initial transition to modern cultivars (Nersting et al., 2006). Results of our experiment show a wide fluctuation of TGW - from $27.2 \mathrm{~g}$ (Lithuanian landrace 'Vietinès 599 ') to $47.2 \mathrm{~g}$ ('Ivory'). Lithuanian cultivars 'Migla DS' and 'Viva DS' were in the medium position according to TGW (37.0 and $36.8 \mathrm{~g}$ ). TGW of Lithuanian genotypes was significantly lower (34.3 g) compared with foreign genotypes (37.9)

Heading time. Nersting et al. (2006) reported that higher yielding cultivars can be later heading cultivars. In our experiment, a moderately weak relationship between heading time and plant grain yield did not corroborate this predication. The moderately weak relationship between heading time and year shows that modern cultivars are neither earlier nor later compared with old genotypes. There was no significant difference in heading time between foreign and Lithuanian genotypes.

Husk content. Low hull content is an important criterion for hulled food oat. It helps to obtain high milling yield (Cowan, Valentine, 2004). Oat grain husk is about 25-30\% (Butt et al., 2008). In our experiment, husk content varied from $21.2 \%$ to $30.0 \%$. There was no significant difference between husk content of foreign and Lithuanian genotypes. The average husk content of the experiment was $25.7 \%$.

Fungal diseases. In our experiment, the average number of loose smut (Ustilago avenae) infected panicles per plot fluctuated in a very wide range from 0.71 ('Stralec') to 119.29 ('Freddy'). In 'Freddy', the number of loose smut infected panicles was significantly higher compared to all the other cultivars. High incidence of loose smut also was observed in 'Aragon' - 74.58 panicles per plot. The infection of newer Lithuanian cultivars was not strong - 'Migla DS' 13.60 and 'Viva DS' 10.5 infected panicles per plot.

Crown rust (Puccinia coronata) is an important disease of oat crops worldwide (Zhao et al., 2020), but in Lithuania it usually appears late and does not cause significant damage. The average point of crown rust in the current experiment in 2013 was 1.49 points, and in 2014 it was 2.34 points. A relatively weak positive relationship was observed between year and crown rust. Lithuanian genotypes were significantly less infected with crown rust compared with foreign cultivars.

\section{Conclusions}

1. The greatest progress of oat genotypes registered, grown or selected in Lithuania was in the increase of yield, hectolitre weight and plant height decrease. The biggest decrease was found in protein content.

2. Newer genotypes tended to have higher thousand grain weight, better resistance to lodging, higher starch and lower fat content and lower resistance to crown rust.

Received 03122019

Accepted 31082020

\section{References}

1. Achleitner A., Tinker N. A., Zechner E., Buerstmayr H. 2008. Genetic diversity among oat varieties of worldwide origin and associations of AFLP markers with quantitative traits. Theoretical and Applied Genetics, 117: 1041-1053. https://doi.org/10.1007/s00122-008-0843-y

2. Ahmad M., Gul-Zaffar Dar Z. A., Habib M. 2014. A review on oat (Avena sativa L.) as a dual-purpose crop. Scientific Research and Essays, 9 (4): 52-59. https://doi.org/10.5897/SRE2014.5820

3. Aro H., Järvenpää E., Könkö K., Huopalahti R., Hietaniemi V. 2007. The characterization of oat lipids produced by supercritical fluid technologies. Journal of Cereal Science, 45: 116-119. https://doi.org/10.1016/j.jcs.2006.09.001

4. Boczkowska M., Tarczyk E. 2013. Genetic diversity among Polish landraces of common oat (Avena sativa L.). Genetic Resources and Crop Evolution, 60: 2157-2169. https://doi.org/10.1007/s10722-013-9984-1

5. Buerstmayr H., Krenn N., Stephan U., Grausgruber H., Zechner E. 2007. Agronomic performance and quality of oat (Avena sativa L.) genotypes of worldwide origin produced under Central European growing conditions. Field Crops Research, 101 (3): 343-351. https://doi.org/10.1016/j.fcr.2006.12.011

6. Butt M. S., Tahir-Nadeem M., Khan M. K., Shabir R., Butt M. S. 2008. Oat: unique among the cereals. European Journal of Nutrition, 47 (2): 68-79. https://doi.org/10.1007/s00394-008-0698-7

7. Cowan S., Valentine J. 2004. New directions in breeding for high quality oats. Proceedings of $7^{\text {th }}$ International Oat Conference. Agrifood Research Reports 51, MTT Agrifood Research Finland, p. 45-50.

8. Danytè V. 2012. Comparison of advanced oat breeding lines in Lithuania. Proceedings of the Latvian Academy of Sciences. Section B. Natural Exact and Applied Sciences, 66: 172-176.

https://doi.org/10.2478/v10046-012-0006-Z 
9. Douhlert C. D., Michael S. McMullen M. S., James J. Hammond J. J. 2001. Genotypic and environmental effects on grain yield and quality of oat grown in North Dakota. Crop Science, 41: 1066-1072. https://doi.org/10.2135/cropsci2001.4141066x

10. Guo L., Tong L.T., Liu L., Zhong K., Qiu J. Zhou S. 2014. The cholesterol-lowering effects of oat varieties based on their difference in the composition of proteins and lipids. Lipids in Health and Disease, 13: 182. https://doi.org/10.1186/1476-511X-13-182

11. Herrera M. P., Gao J., Vasanthan T., Temelli F. Henderson K. 2016. $\beta$-Glucan content, viscosity, and solubility of Canadian grown oat as influenced by cultivar and growing location. Canadian Journal of Plant Science, 96: 183-196. https://doi.org/10.1139/cjps-2014-0440

12. Kulikauskas A., Sprainaitienè J. 1998. Oat breeding in Lithuania. Liekis A. (ed.) Plant breeding. Lietuvos mokslas, p. 59-63 (in Lithuanian)

13. Leišová-Svobodová L., Michel S., Tamm I., Chourová M., Janovska D., Grausgruber H. 2019. Diversity and prebreeding prospects for local adaptation in oat genetic resources. Sustainability, 11: 6950. https://doi.org/10.3390/su11246950

14. Michel S., Löschenberger F., Ametz, C. Pachler B., Sparry E., Bürstmayr H. 2019. Combining grain yield, protein content and protein quality by multi-trait genomic selection in bread wheat. Theoretical and Applied Genetics, 132: $2767-2780$ https://doi.org/10.1007/s00122-019-03386-1

15. Mut Z., Erbaş Köse Ö. D., Akay H. 2016. Grain yield and some quality traits of different oat (Avena sativa $\mathrm{L}$.) genotypes. International Journal of Environmental and Agriculture Research, 2 (12): 83-88.

16. Mut Z., Akay H., Erbaş Köse Ö. D. 2018 (a). Grain yield, quality traits and grain yield stability of local oat cultivars. Journal of Soil Science and Plant Nutrition, 18 (1): 269-281. https://doi.org/10.4067/S0718-95162018005001001

17. Mut Z., Erbaş Köse Ö. D., Akay H. 2018 (b). Variation of some physical and chemical quality traits of the grains in different parts of the oat panicle. International Journal of Agriculture and Biology, 20: 268-276. https://doi.org/10.17957/IJAB/15.0487

18. Nersting L. G., Andersen S. B., Bothmer von R., Gullord M., Jørgensen R. B. 2006. Morphological and molecular diversity of Nordic oat through one hundred years of breeding. Euphytica, 150: 327-337.

https://doi.org/10.1007/s10681-006-9116-5

19. Peterson D. M., Wesenberg D. M., Burrup D. E., Erickson C. A. 2005. Relationships among agronomic traits and grain composition in oat genotypes grown in different environments. Crop Science, 45 (4): 1249-1255.

https://doi.org/10.2135/cropsci2004.0063

20. Punia S., Sandhu K. S., Dhul S. B., Siroha A. K., Purewal S. S., Kaur M., Kidwai M. K. 2020. Oat starch: physico-chemical, morphological, rheological characteristics and its applications - a review. International Journal of Biological Macromolecules, 154: 493-498. https://doi.org/10.1016/j.ijbiomac.2020.03.083

21. Shah W. A., Bakht J., Shafi M., Khan M. A. 2002. Yield and yield components of different cultivars of wheat barley and oat under rainfed conditions. Asian Journal of Plant Science, 1 (2): 148-150.

https://doi.org/10.3923/ajps.2002.148.150

22. Tamm I. 2003. Genetic and environmental variation of grain yield of oat varieties. Agronomy Research, 1: 93-97.

23. WRB. 2014. World reference base for soil resources. World Soil Resources Reports No. 106. FAO, 189 p.

24. Wu W., Ma B. L. 2019. Erect-leaf posture promotes lodging resistance in oat plants under high plant population. European Journal of Agronomy, 103: 175-187. https://doi.org/10.1016/j.eja.2018.12.010

25. Yan H., Bekele W. A., Wight C. P. Peng Y., Langdon T., Latta R. G., Fu Y. B., Diederich A., Howarth C. J., Jellen E. N., Boyle B., Wei Y., Tinker N. A. 2016. High-density marker profiling confirms ancestral genomes of Avena species and identifies D-genome chromosomes of hexaploid oat. Theoretical and Applied Genetics, 129: 2133-2149. https://doi.org/10.1007/s00122-016-2762-7

26. Zhao J., Kebede A. Z., Menzies J. G., Paczos-Grzęda E., Chong J., Mitchell Fetch J. W., Beattie A. D., Peng Y.-Y., McCartney C. A. 2020. Chromosomal location of the crown rust resistance gene Pc98 in cultivated oat (Avena sativa L.). Theoretical and Applied Genetics, 133 (4): 1109-1122. https://doi.org/10.1007/s00122-020-03535-x

27. Zhou M. X., Glennie-Holmes M., Roberts G. L., Robards K., Helliwell S. 1999. The effect of growing sites on grain quality of oats and pasting properties of oat meals. Australian Journal of Agriculture research, 50: 1409-1406. https://doi.org/10.1071/AR99025

ISSN 1392-3196 / e-ISSN 2335-8947

Zemdirbyste-Agriculture, vol. 107, No. 4 (2020), p. 323-328

DOI $10.13080 /$ z-a.2020.107.041

\title{
Avižų veislių, augintų Lietuvoje, savybių kaitos tendencijos
}

\author{
V. Danytè, A. Gorash, A. Liatukienè, Ž. Liatukas \\ Lietuvos agrarinių ir miškų centro Žemdirbystès institutas
}

\section{Santrauka}

Tyrimas atliktas Lietuvos agrarinių ir miškų mokslų centro Žemdirbystės institute. Analizuoti sẻjamosios avižos (Avena sativa L.) 37 genotipai, kurie nuo 1934 iki 2013 metų buvo registruoti kaip veislès, auginti (kol nebuvo registracijos) arba surinkti Lietuvoje. Tyrimui atlikti buvo įrengti tikslieji lauko bandymai. Pasėliu priežiūrai buvo taikyta tradicinė technologija. Apskaičiuota koreliacija tarp genotipų savybių ir registracijos, auginimo arba surinkimo metų. Nustatyta, kad selekcijos metu labiausiai padidèjo grūdų derlius $(R=0,73)$, sumažèjo augalų aukštis $(R=-0,57)$ ir padidejo saiko svoris $(R=0,53)$; labiausiai sumažejo baltymų kiekis grūduose $(R=-0,55)$. Naujosios veislès turi tendenciją būti atsparesnès išgulimui, turèti didesnị 1000 grūdų svorị, didesnị krakmolo ir mažesnį riebalų kiekị, mažesnị atsparumą vainikuotosioms rūdims.

Reikšminiai žodžiai: Avena sativa, genotipai, derlius. 